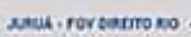

telipe betander

\title{
DiReito À
}

SAÚDE

Praticns Sociais Roivinglicatorins

osua Efetivaçio

vio

幽祖

Direito à Saúde: práticas sociais reivindicatórias e sua efetivação.

Right to Health: claimed social practices and their effectiveness.

\section{Jarbas Ricardo Almeida Cunha}

Especialista em Direito Sanitário (Fiocruz). Analista Técnico de Políticas Sociais do Ministério do Desenvolvimento Social e Combate à Fome. Brasília/DF, Brasil.

O livro Direito à Saúde: Práticas Sociais Reivindicatórias e sua Efetivação, de Felipe Dutra Asensi, aborda as táticas e estratégias de reivindicação do direito à saúde no Brasil e em Portugal analisando sociedade, cultura e instituições para a construção dos direitos e para a articulação dos atores sociais na sua efetivação.

O livro está dividido em três partes: a primeira denomina-se "Direito como Efeito de Superfície"; a segunda "Saúde e Instituições Jurídicas" e a terceira "Condicionantes da Variação de Estratégias Reivindicativas".

A primeira parte, "Direito como Efeito de Superfície", está dividida em quatro capítulos. No primeiro, o autor, ancorado em clássicos da Ciência Política e do Direito, aborda a relação entre Direito e Política, ratificando a forte ligação entre esses conceitos e analisando criticamente suas bases de sustentação: a associação umbilical entre direito, território e Estado, a assunção da lei como fonte primária e predominante do direito, e a centralidade do Poder Judiciário no processo de reivindicação e efetivação de direitos.

No segundo capítulo "Direito e Pluralismo" o autor aprofunda sua análise crítica abordando a produção de direitos para além da oficialidade estatal, 
discutindo a perspectiva pluralista e sua relação com o campo do direito, e os diversos pluralismos jurídicos, com base em autores como Boaventura de Sousa Santos e Robert Dahl (p. 72).

No terceiro capítulo "Direito e Governamentalidade", ele analisa as pluralidades em torno do conceito da Teoria de Governo, iniciando sua reflexão com a dupla dimensão proposta por Foucault (p. 81-82): a dimensão diagnóstica e a genealógica do governo e dos direitos, destacando suas diversas possibilidades de ação. Ainda destaca, com base em Foucault, que os movimentos do governo, da população e da economia política são os que problematizam o Estado, a cidadania e os direitos (p. 84). Adentra, também, no elemento central da perspectiva epistemológica de Foucault que é a ideia de genealogia, inter-relacionando esta com a ideia de direitos, soberania e exercício do poder. Com base no contratualismo, principalmente de Hobbes e Rousseau, e no absolutismo italiano de Maquiavel (p. 91), analisa a relação entre Governo e Estado e, por fim, relata os estudos de governamentalidade, concluindo que "a escolha das prioridades governamentais com frequência vem acompanhada da interseção entre governo, população e instituições jurídicas e sanitárias, de modo que o direito à saúde recebe uma pluralidade de significações a depender da experiência de cada país. O resultado é uma pluralidade de estratégias de reivindicação deste direito" (p. 115).

No último capítulo da primeira parte, denominado "Superfície e Fundo do Direito", o autor traça um paralelo entre a superfície do Direito (suas leis, centralidade do Judiciário, predomínio do Estado) - que podemos interpretar como uma aparência do Direito, bem ordenada e compacta, fiel ao positivismo formalista - e o fundo do Direito, onde se desvendaria a essência do Direito, o "direito vivo" das práticas sociais, com influência da política, do pluralismo e da governamentalidade.

Na segunda parte da obra, "Saúde e Instituições Jurídicas", o autor inicia, no capítulo denominado "O Direito à Saúde no Brasil e em Portugal", a análise comparativa entre Brasil e Portugal ao sistematizar como foi construído o direito à saúde nesses dois países. Inicia com as "Concepções de Saúde ao Longo da História Brasileira", descrevendo desde a cultura do favor, passando pelo privatismo e pelo direito à saúde apenas aos que estavam inseridos no mercado de trabalho, até analisar as consequências da constitucionalização do 
direito à saúde em 1988 para os dias atuais. Destaca os princípios e, principalmente, a participação popular na construção do direito sanitário brasileiro, desde o Movimento da Reforma Sanitária até a participação em conselhos e conferências de saúde.

Portugal diferencia-se da construção sanitária brasileira, pois, lá, o Direito Sanitário foi resultado da inserção de organismos internacionais, como a Organização Mundial da Saúde (OMS), via Estado e, principalmente, responsabilização individual, e se iniciou na década de 1940, passando pelas consequências da Revolução dos Cravos, na década de 1970, até a entrada do país na União Europeia e o crescimento da influência de tratados e organismos internacionais na atualidade, com pouca participação popular. Há quatro modos de produção em saúde em Portugal (p. 176): estatal, capitalista (privado), popular e europeu, todos girando em torno do Serviço Nacional de Saúde (SNS).

No capítulo "Judicialização e Desjudicialização", o autor inicia com a importante diferenciação entre judicialização e juridicização. Enquanto o primeiro conceito diz respeito aos conflitos que são levados ao Judiciário por meio de algum instrumento processual, o segundo diz respeito aos conflitos que não são levados ao Judiciário, mas que são discutidos de forma prioritariamente jurídica, em situações pré-processuais, como a mediação, a conciliação e a arbitragem (p. 191).

Também é analisada a forte judicialização ocorrida no Brasil, centrada nas demandas ao Poder Judiciário, e sua ausência em Portugal, com preponderância da juridicização, onde juízes não são bem valorizados, inclusive financeiramente, e a importância que é dada, em terras lusitanas, ao Poder Executivo: uma inversão, se comparado ao caso brasileiro.

Na terceira e última parte, denominada "Condicionantes da Variação de Estratégias Reivindicativas”, também há dois capítulos. No primeiro, "Estratégias Reivindicativas", o autor destaca os condicionantes que influenciam a ação dos atores sociais que envolvem três tipos de relações: a) saúde e solidariedade, responsabilizando ora o Estado (Brasil), ora o indivíduo (Portugal); b) participação social e cultura política, destacando a influência dos movimentos sociais (Brasil) e de prevalência internacional (Portugal) e; c) judicialização e desjudicialização, sobre a relação entre Judiciário e sociedade 
que pode ser de aproximação com o cidadão (Brasil) ou desjudicialização (Portugal).

No último capítulo, "Oportunidades Políticas e Direito à Saúde", destacam-se semelhanças entre Brasil e Portugal - tanto nos sistemas de saúde como nos sistemas judiciários - que podem contribuir para uma aproximação de oportunidades políticas entre ambos os países (p. 343-346). Nos sistemas de saúde: saúde como um direito constitucional; sistemas de saúde contemporâneos, sistemas de saúde universais e públicos; pressupõem participação social e promovem regionalização dos serviços. E no sistema judiciário: estrutura hierarquizada e burocratizada, tradição de civil law, "law in books x law in action", ingresso predominante por meritocracia e obstáculos de acesso à justiça e ao direito.

O livro apresenta ainda diagramas, gráficos, mapa, quadros e tabelas com dados sobre o direito à saúde no Brasil e em Portugal e constitui importante leitura não somente para aqueles que desejam se aprofundar no estudo comparado do Direito Sanitário entre os dois países, mas também para todos que tenham interesse sobre as estratégias e formas de efetivação da saúde como direito e na utilização de mecanismos judiciais e extrajudiciais, numa perspectiva participativa e solidária.

ASENSI, Felipe Dutra. Direito à Saúde: Práticas Sociais Reivindicatórias e sua Efetivação. Curitiba: Juruá, 2013. ISBN 978853623985-9 